\title{
KONSERVASI KOLEKSI TINGGALAN KOLONIAL DI PULAU MOROTAI (MALUKU UTARA)
}

\author{
Sri Wahyuni dan Yudhi Atmaja Hendra Purnama \\ Balai Konservasi Borobudur \\ Email : nyun2_euro@yahoo.com
}

\begin{abstract}
Abstrak : Konservasi Koleksi Tinggalan Kolonial di Pulau Morotai dilakukan oleh BPCB Ternate sebagai instansi pelestarian cagar Budaya. Pelestarian dimaksudkan untuk menjaga keterawatan benda yang memiliki nilai penting karena merupakan salah satu bukti sejarah Perang Dunia II. Tahap pertama dalam melakukan konservasi adalah pendokumentasian koleksi sebelum di konservasi, selama proses konservasi, dan setelah konservasi. Koleksi peninggalan kolonial yang dikonservasi meliputi koleksi berbahan gelas, logam, porselen, dan lainnya. Bahan yang digunakan untuk konservasi koleksi yang berbahan gelas adalah cuka, kerikil, dan sabun serta air. Sedangkan bahan yang digunakan untuk konservasi jenis logam terutama perunggu dan kuningan adalah campuran antara jeruk nipis dan soda kue (sodium bikarbonat) yang dipastakan. Untuk koleksi berbahan besi digunakan asam sitrat dengan konsentrasi $5 \%$. Apabila Asam sitrat tidak dijumpai dapat diganti dengan menggunakan air jeruk nipis $(\mathrm{pH} 4-5)$ karena di dalam jeruk juga mengandung asam sitrat. Adapun bahan yang digunakan untuk pelapisan logam adalah minyak singer. Dalam melakukan konservasi porselen digunakan air hangat yang diberi sabun sedangkan untuk koleksi yang ada keraknya dikonservasi dengan menggunakan pasta yaitu campuran soda kue (sodium bikarbonat) dengan air jeruk.

Metode penyimpanan sementara koleksi peninggalan kolonial di Morotai yang sudah selesai dikonservasi dan yang akan dipamerkan di Museum Perang Dunia II dilakukan dengan cara membungkus setiap koleksi dengan tissue dan kertas koran. Setelah di bungkus kemudian diikat agar tidak terkena kotoran/debu, selanjutnya dimasukkan dalam container box. Untuk menyerap kelembaban di dalam container box ditabahkan kapur tulis.

Berbagai macam koleksi peninggalan kolonial Perang dunia II dapat dilakukan konservasi dengan menggunakan bahan yang mudah di peroleh dipasaran seperti jeruk nipis, soda kue (sodium bikarbonat), cuka, sabun, dan kerikil. Untuk koleksi jenis logam seperti perunggu, kuningan, dan uang koin serta koleksi porselen yang berkerak dapat menggunakan jeruk nipis dan soda kue yang telah dipastakan. Pasta dari bahan jeruk nipis dan soda kue terbukti efektif untuk membersihkan korosi yang ada pada koleksi logam. Adapun koleksi berbahan gelas/botol yang berkerak dapat dikonservasi dengan menggunakan cuka, kerikil, sabun serta air. Formula tersebut terbukti efektif mengangkat endapan kerak yang menempel dalam botol.
\end{abstract}

Kata kunci : Morotai, Koleksi Peninggalan Kolonial PD II, Konservasi

Abstract : Conservation of Collection from Colonial Period In Morotai Island was conducted by Cultural Property Preservation Office of Ternate. The conservation was aimed to preserve the state of conservation of objects that have significant value, because they are historical remains of World War II. First stage consists of documentation of collection before conservation, includes glass, metal, and porcelain objects. Materials used for glass object are vinegar, gravel, soap and water. Materials used for metal object, especially bronze and brass, are paste mixture of lemon and baking soda (sodium bicarbonate). For iron, citric acid $5 \%$ concentration is used. If citric acid is rare, it could be replace by lemon water $(\mathrm{pH} 4-5)$, because lemon contains citric acid. Material used for metal coating is singer oil. In the conservation of porcelain, warm water mixed with soap is used, while the crust is eliminated by paste of baking soda (sodium bicarbonate) and lemon water.

Temporary storage is done by wrapping each collection with tissue and newsprint, before the collection is shown in World War II Museum. After the wrapping, each collection was tied then put into container box, in order to avoid dust. Chalk is put inside the box to absorb humidity.

Collection from World War II period can be conserved by easy access commercial product such as lemon, baking soda (sodium bicarbonate), vinegar, soap, and gravel. For metal object such as bronze, bass, and coin as well as crusted porcelain, lemon and baking soda paste could be used. Paste made from lemon and baking soda is proven to be effective in cleaning corrosion in metal object. Meanwhile, crusted 
glass/bottle can be conserved using vinegar, gravel, soap, and water. The formula is proven to be effective in removing crust sticking into bottle.

Keywords: Morotai, Collection from World War II Colonial Period, Conservation

\section{BAB I. PENDAHULUAN}

\section{A. Latar Belakang}

Indonesia merupakan sebuah negara kepulauan yang kaya akan sumber alam maupun bukti-bukti sejarah masa lampau dari jaman prasejarah maupun jaman perang kemerdekaan. Salah satu kepulauan yang menyimpan banyak nilai sejarah pada masa kolonial adalah Kepulauan Morotai. Morotai terletak di propinsi Maluku Utara yang merupakan pemekaran dari Kabupaten Halmahera Utara.

Bukti-bukti peninggalan masa kolonial di kepulauan ini sangat banyak dijumpai, di antaranya berupa bangunan gedung, benteng, tugu, gerbang, jembatan, pelabuhan, dan makam/kuburan. Buktibukti tersebut menggambarkan secara jelas bahwa pulau ini merupakan salah satu tempat yang penting pada masa lalu sebagai sebuah jalur pelayaran internasional. Selain bukti-bukti sejarah yang berupa bangunan, juga banyak sekali ditemukan peninggalan-peninggalan artefaktual yang berupa peralatan yang digunakan untuk kegiatan seharihari (sendok, garpu, dII), maupun peralatan yang difungsikan sebagai artefak untuk pertahanan (senapan, peluru, granat, dII).

Mengingat nilai sejarah yang sangat tinggi, sedangkan umur koleksi tersebut sudah sangat tua, maka dari itu benda-benda tersebut rawan terhadap kerusakan. Untuk itu maka langkahlangkah konservasi untuk menjaga agar koleksi tersebut tetap terjaga kelestariannya harus selalu dilakukan.

Kegiatan perawatan atau konservasi difokuskan pada Koleksi-koleksi tinggalan masa perang dunia II yang akan dipamerkan pada event bahari tingkat internasional yaitu Sail Morotai 2012.

\section{B. Tujuan}

Tujuan kegiatan ini adalah untuk melakukan usaha pembersihan terhadap koleksi-koleksi yang ada untuk meningkatkan keterawatan koleksikoleksi tersebut.

\section{BAB II. TINJAUAN PUSTAKA}

Koleksi yang disimpan pada Museum Mini (sebutan lokasi) terdiri dari koleksi berbahan logam seperti proyektil peluru, uang koin, tempat minum, gelas (berupa botol), dan porselen (berupa tempat menggerus obat).

\section{A. Logam}

Koleksi berbahan logam berupa Selongsong peluru atau patrun yang merupakan wadah yang membungkus proyektil peluru dan terdiri dari propelan (biasanya bubuk mesiu), rim, dan primer. Bubuk mesiu berfungsi sebagai pencetus ledakan yang mendorong proyektil peluru dengan energi kinetik. Selongsong peluru baru dikenal pada penggunaan amunisi senjata api modern. Senapan api jenis awal seperti senapan kopak, senapan lontak atau pemuras belum mengenal penggunaan "selongsong" pada sebuah peluru. Selongsong besi dari sebuah amunisi sering dilapisi dengan lapisan tipis polimer ataupun tembaga yang melindunginya terhadap korosi. Beberapa amunisi juga terbuat dari aluminium. Walaupun lebih elastik daripada besi, namun kurangnya daya tarik dari aluminium saat proses isi ulang menghambat proses pengisian ulang senjata.

\section{B. Gelas}

Gelas adalah benda yang transparan, lumayan kuat, biasanya tidak bereaksi dengan barang kimia, tidak aktif secara biologi, dan bisa dibentuk dengan permukaan yang sangat halus dan kedap air. Oleh karena sifatnya yang sangat ideal, gelas banyak digunakan di berbagai bidang kehidupan. Sifat kaca ini bisa dimodifikasi dan bahkan bisa diubah seluruhnya dengan proses kimia atau dengan pemanasan.

\section{Porselen}

Porselen (Porcelain) adalah jenis keramik bakaran suhu tinggi yang dibuat dari lempung jenis kaolin, yang dicampur dengan alumina (feldspar), dan silica (pasir). Pada umumnya porselen dipijar sampai suhu $1350^{\circ} \mathrm{C}$ atau $1400^{\circ} \mathrm{C}$, bahkan ada yang lebih tinggi lagi hingga mencapai $1500^{\circ}$. Oleh karena badan porselen jenis ini berwarna putih, bahkan bisa tembus cahaya, maka sering disebut keramik putih.. Porselen yang tampaknya tipis dan rapuh sebenarnya mempunyai kekuatan karena struktur dan teksturnya rapat serta keras seperti gelas. Oleh karena keramik ini dibakar pada suhu tinggi maka dalam bodi porselen terjadi penggelasan 
atau vitrifikasi. Secara teknis keramik jenis ini mempunyai kualitas tinggi dan bagus. Di samping mempunyai daya tarik tersendiri karena keindahan dan kelembutan khas porselen, juga bahannya sangat peka dan cemerlang terhadap warna-warna glasir.

\section{BAB III. METODOLOGI PELAKSANAAN}

Pembersihan koleksi dilaksanakan berdasarkan bahan masing-masing objek. Secara garis besar koleksi tersebut terbuat dari 3 jenis bahan yaitu objek berbahan gelas/kaca, objek berbahan logam, dan objek berbahan porselen.

Prosedur kerja yang dilakukan dalam kegiatan ini adalah :

1. Pendokumentasian Objek.

Pendokumentasin ini bertujuan agar segala kegiatan yang dilakukan dapat terekam dengan baik antara sebelum dan sesudah kegiatan perawatan. Adapun parameter-parameter yang dilaksanakan adalah :

a. Objek Berbahan Gelas

Labelisasi Objek
1) Nama Objek
2) Bahan Dasar Objek
3) Warna
4) Foto

b. Objek Berbahan Logam

Labelisasi Objek
1) Nama Objek
2) Bahan Dasar
3) Warna
4) Foto

c. Objek Berbahan Porselen Labelisasi objek
1) Nama Objek
2) Bahan Dasar
3) Warna
4) Foto

2. Observasi keterawatan tiap-tiap objek

Setelah dilakukan pendokumentasian, langkah berikutnya adalah observasi tingkat keterawatan terhadap masing-masing objek. Tujuan observasi keterawatan ini adalah untuk mengetahui sejauh mana tingkat kerusakan yang terjadi sebagai acuan untuk menentukan metode perawatan yang efektif, efisien, serta aman bagi benda maupun pelaksana kegiatan itu sendiri.

Parameter-parameter observasi tingkat keterawatan yaitu :

1) Jenis kerusakan

2) Tingkat kerusakan

3. Alat dan bahan

a. Alat
1) Sikat nilon
2) Sikat gigi
3) Ember
4) Tissue
5) Kapas

b. Bahan

Bahan yang dipersiapkan dalam kegiatan ini meliputi bahan alami dan bahan kimia.
1) Bahan Alami Jeruk nipis
2) Bahan Kimia
- Soda kue(Sodium Bikarbonat)
- Cuka(Asam Asetat)
- Asam Sitrat
3) Bahan untuk pelapis/coating
- Minyak singer

4. Metode Pembersihan.

1) Objek berbahan gelas.

Langkah-langkah :

- Ke dalam botol gelas dimasukkan satu sendok cuka;

- Ditambahkan sedikit kerikil ke dalam botol gelas;

- Ditambahkan setengah sendok sabun cair ke dalam botol gelas;

- Dilakukan penambahan air hangat ke dalam botol gelas hingga volumenya setengah botol gelas;

- Dilakukan penggocokkan botol selama 20 menit dan dilakukan berulangulang;

- Untuk kotoran atau endapan yang sulit dibersihkan maka larutan didiamkan selama satu malam;

- Tahapan akhir dari pembersihan ini dengan cara membilas botol gelas dengan menggunakan air.

2) Objek berbahan logam.

a. Perunggu

- Dilakukan pencampuran jeruk nipis dengan soda kue, hingga berbentuk pasta;

- Permukaan perunggu yang terdapat korosi diolesi dengan pasta selama kurang lebih 15 menit. Untuk objek yang terbengkalai bertahun-tahun atau mempunyai tingkat korosi yang tinggi, waktu periode pembersihan direkomendasikan lebih lama;

- Dilakukan pembilasan pada area 
kecil dari obyek yang diolesi dengan pasta untukmelihat keefektifannya. Halini dilakukan untuk menentukan apakah periode penempelan yang lebih lama dibutuhkan atau tidak. Pada perunggu yang terlihat cerah dan terang, dilakukan pembilasan dengan menggunakan air hangat, perunggu yang masih terdapat korosi dibiarkan campuran pasta lebih lama lagi sehingga pembersihan yang optimal benarbenar tercapai;

- Tahapan akhir dilakukan pelapisan pada obyek dengan menggunakan minyak singer setelah obyek benar-benar kering dan bersih dari korosi.

b. Besi

- Dilakukan pelarutan $50 \mathrm{gr}$ asam sitrat dalam 1 liter air;

- Pada objek dilakukan perendaman dalam larutan asam sitrat hingga satu malam;

- Pembersihan denganmenggunakan sikat;

- Pembilasan pada obyek yang telah dibersihkan dengan menggunakan air;

- Obyek dikeringkan dengan menggunakan hairdryer atau pengeringan langsung di bawah terik sinar matahari;

- Tahap akhir dilakukan pelapisan pada obyek dengan menggunakan minyak singer setelah obyek benar-benar kering dan bersih dari korosi.

c. Aluminium

- Dilakukan pencampuran jeruk nipis dengan soda kue (sodium bikarbonat) hingga berbentuk pasta;

- Pengolesan pada obyek yang terdapat korosi dengan menggunakan pasta;

- Pada obyek yang diolesi pasta dilakukan penggosokan dengan menggunakan sikat halus;

- Pembilasan pada obyek dengan menggunakan air sampai bersih;

- Dilakukan pelapisan pada obyek dengan menggunakan minyak singer setelah obyek benar-benar kering dan bersih dari korosi.

3) Obyek Porselen

- Dilakukan pencampuran jeruk nipis dengan soda kue hingga berbentuk pasta;

- Pengolesan pada obyek yang berkerak dengan menggunakan pasta;

- Pada obyek yang telah diolesi pasta dilakukan penggosokan dengan menggunakan sikat halus;

- Dilakukan pembilasan pada obyek dengan menggunakan air bersih;

- Tahap akhir dilakukan pengeringan pada obyek dengan menggunakan hairdryer atau pengeringan langsung dengan terik matahari.

5. Metode penyimpanan

Metode penyimpanan merupakan tahapan yang sangat penting dilakukan setelah koleksi dilakukan pembersihan.

Metode penyimpanan yang dilakukan dalam kegiatan ini bersifat sementara sebelum koleksi dipamerkan dalam museum Perang Dunia II. Tujuan dari penyimpanan koleksi adalah menjaga agar koleksi yang telah dibersihkan terhindar dari debu. Hal ini dikarenakan tempat penyimpanan koleksi (museum mini) lantai langsung berhubungan dengan tanah. Adapun cara penyimpanan yang dilakukan adalah dengan membungkus setiap koleksi dengan menggunakan kertas tissue dan kertas koran. Koleksi dimasukkan dalam boks kontainer yang didalamnya terdapat kapur tulis untuk menyerap kelembaban.

\section{BAB IV. HASIL DAN PEMBAHASAN}

\section{A. Permasalahan kerusakan koleksi dan cara penanganannya}

Museumminimenyimpan berbagaijeniskoleksi yang cukup beragam, namun yang paling dominan adalah koleksi berbahan logam. Hasil inventarisasi yang dilakukan BPCB Ternate, menunjukkan bahwa koleksi jenis peluru merupakan koleksi yang paling banyak diantara koleksi yang lain (botol gelas dan koleksi dari porselen).

a. Koleksi Berbahan Gelas

Koleksi obyek berbahan gelas yang dibersihkan berjumlah 18 buah, yang kesemuanya berbentuk botol dengan ukuran beragam serta mempunyai fungsi yang beragam, baik berupa botol minuman, botol tinta dan lain sebagainya.

Hasil dari observasi tingkat keterawatan koleksi 


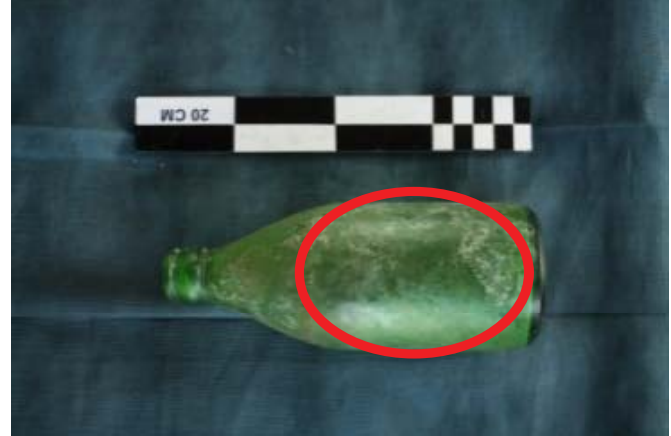

Foto 1. Endapan pada koleksi berbahan gelas

menunjukkan bahwa seluruh koleksi berbahan gelas terlapisi pengotoryang berupa debu, endapan tanah kering, serta ada lapisan-lapisan endapan putih pada dinding-dinding botol. Endapan putih ini dimungkinkan merupakan endapan kalsium dan magnesium. Hal ini dikarenakan air yang mengandung sejumlah kalsium dan magnesium yang volumenya besar, ketika dingin terjadi nodanoda putih pada dinding gelas. Hal ini sangat masuk akal karena botol-botol tersebut telah lama terkubur dalam tanah yang mengandung garamgaram kalsium dan magnesium.

Cara penanganan yang dilakukan untuk menghilangkan endapan putih yang ada dalam botol gelas dilakukan dengan cara botol diberi kerikil, cuka dan sabun kemudian tunggu beberapa saat dan digojok selama 20 menit. Cuka yang bersifat asam lemah, mempunyai kemampuan untuk mengkelat logam sehingga ketika bereaksi dengan sabun mampu membentuk busa $\left(\mathrm{CO}_{3}\right)$ dan berikatan dengan kalsium maupun magnesium membentuk $\mathrm{CaCO}_{3}$ atau $\mathrm{MgCO}_{3}$ yang sangat mudah larut dalam air.

Pembersihan kerak dalam botol dengan cara digojok dinilai kurang maskimal maka pembersihan secara mekanik perlu dilakukan. Hal tersebut dimaksudkan untuk mencapai hasil yang optimal mengingat kerak yang menempel pada botol sudah sangat lekat menempel, sehingga sangat susah dihilangkan tanpa pembersihan mekanik.

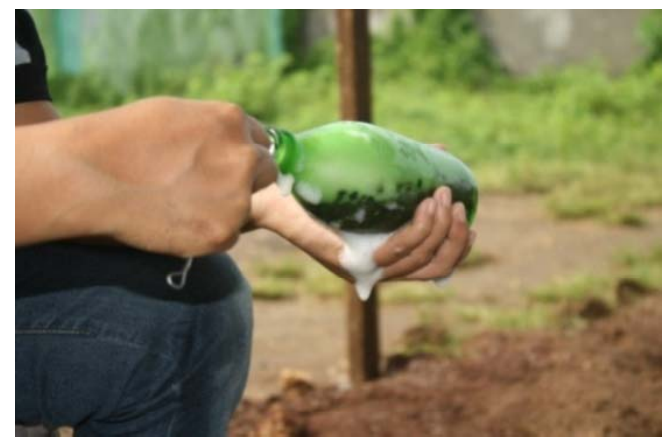

Foto 2. Pembersihan secara mekanik dengan menggunakan sikat

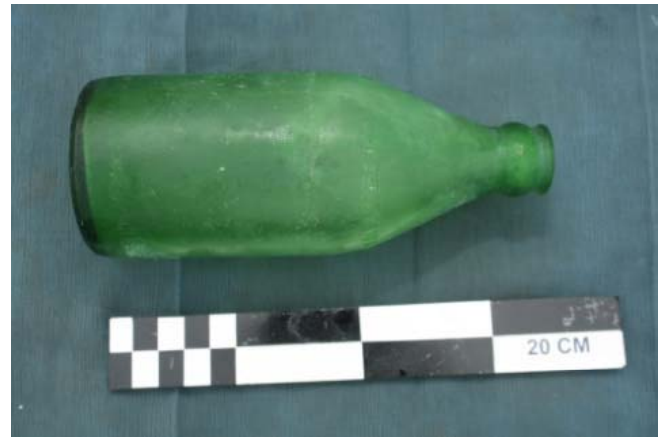

Foto 3. Koleksi botol gelas setelah dibersihkan

\section{b. Koleksi Berbahan Logam}

Koleksi logam yang dikonservasi berupa selongsong proyektil, senjata, uang logam, roket, name tag tentara dalam berbagai bentuk, dll.

Bahan dasar masing-masing koleksi logam tersebut juga variatif, misalnya peluru umumnya terbuat dari tembaga yang dilapisi kuningan, proyektil terbuat dari besi.

Koleksi berbahan logam lainnya berupa koin mata uang. Koleksi mata uang terdiri dari beberapa jenis, berukuran besar maupun kecil. Bahan dasar dari mata uang tersebut secara perunggu, namun ada pula yang berbahan perak.

1. Koleksi berbahan dasar tembaga.

Koleksi berbahan dasar tembaga ini rata-rata berupa peluru dengan berbagai jenis ukuran baik kecil maupun besar. Proyektil peluru terbuat dari logam tembaga yang dilapisi dengan seng $(Z n)$ pada bagian luarnya. Peluru yang masih baru terlihat kuning, tetapi proyektil yang telah lama bagian pelapisnya terkelupas dan yang terlihat adalah warna tembaga seperti yang ditemukan di wilayah Morotai.

Dari hasil observasi menunjukkan bahwa proyektil peluru yang ada, rata-rata pelapis kuningan di bagian permukaannya telah terkelupas. Namun ada juga proyektil peluru yang masih bagus sehingga warnanya terlihat kekuningan.

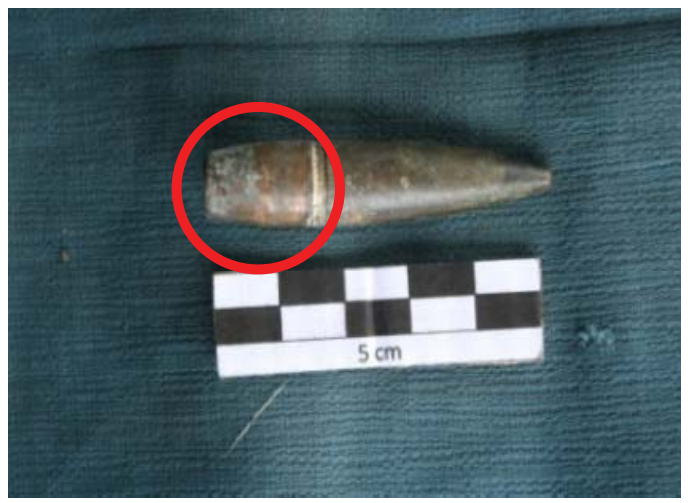

Foto 4. Korosi dan pengeluasan pada permukaan peluru 


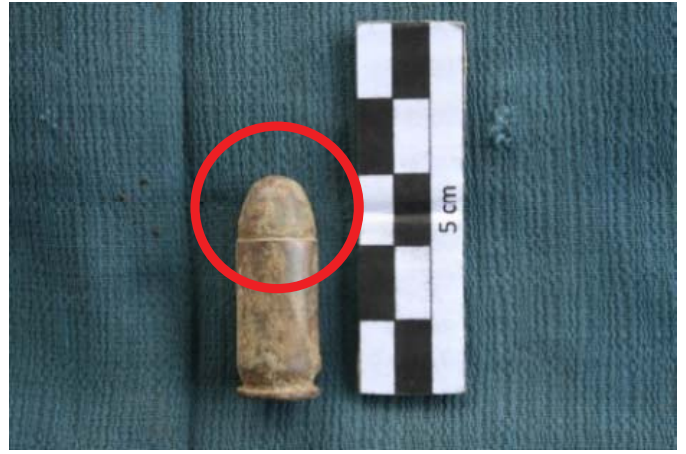

Foto 5. Pengelupasan pada Permukaan Peluru

Koleksi yang berbahan logam yang lain adalah koleksi koin. Dari hasil observasi menunjukkan bahwa pada koin logam rata-rata telah terbentuk lapisan patina. Lapisan patina terbentuk karena reaksi oksidasi antara karbonat dengan lingkungan/cuaca. Ketika koin terekspos panas atau kontaminan dari lingkungan sekitar, maka warnanya akan berubah.

Setelah beberapa waktu, koin berbahan perak akan berubah menjadi kehitaman karena reaksi kimia. Koin tembaga akan berubah menjadi warna coklat pada tulisan (2,5 Cent Netherlands Indie/ benggol) ditemukan beberapa variasi warna patina, yaitu coklat tua, coklat muda, coklat kemerahan, dan coklat kekuningan. Hal ini terjadi karena reaksi oksidasi. Koin nikel berubah menjadi abu redup. Selain itu, ada beberapa mata uang mengalami korosi yang berwarna kehijauan.

Tindakan penghilangan korosi dilakukan dengan cara menempelkan pasta yang terbuat dari campuran antara jeruk nipis dan soda kue (sodium bikarbonat). Pasta tersebut kemudian ditempelkan pada permukaan koleksi logam yang mengalami korosi (permukaan berwarna hijau).

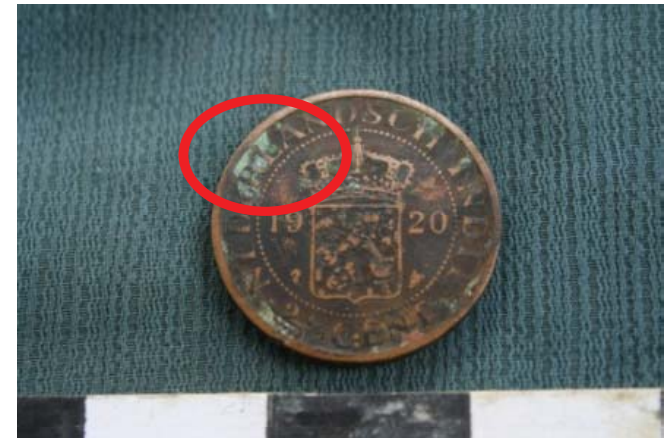

Foto 6. Karat berwarna hijau pada permukaan

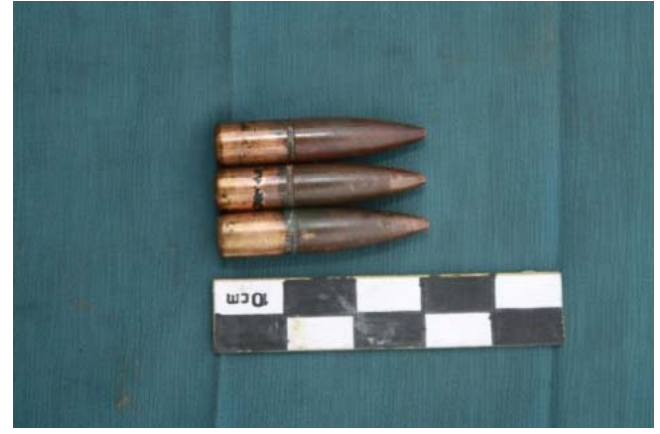

Foto 7. Koleksi peluru setelah dibersihkan

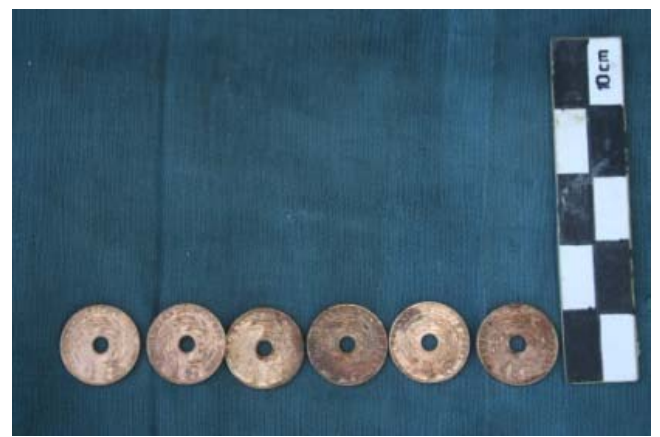

Foto 8. Koleksi koin setelah dibersihkan dan dilapisi dengan minyak singer

Penempelan dilakukan selama beberapa menit dengan memperhatikan tingkat ketebalan korosi. Hal ini dilakukan supaya patina yang ada pada permukaan logam tidak tergerus.Tahapan selanjutnya setelah penempelan adalah pembilasan dengan menggunakan air bersih sambil digosok menggunakan sikat gigi secara perlahan-lahan. Tahap akhir setelah kering adalah pelapisan menggunakan minyak singer. Hal ini bertujuan untuk melapisi agar menghambat terjadinya korosi.

\section{Koleksi berbahan dasar besi}

Koleksi logam berbahan dasar besi permasalahan yang tampak jelas adalah berupa karat. Korosi atau perkaratan logam merupakan proses oksidasi sebuah logam dengan udara atau

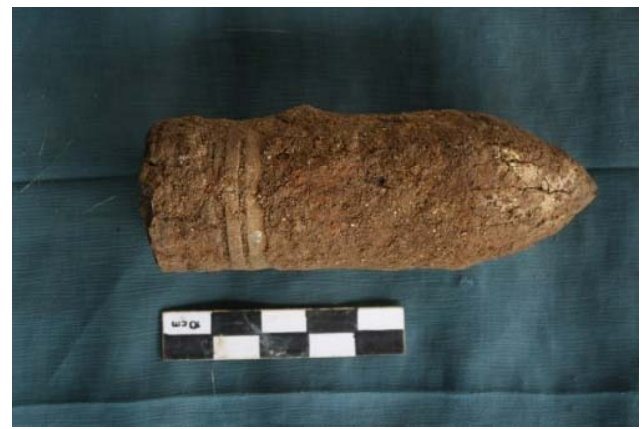

Foto 9. Koleksi berbahan logam (peluru) 


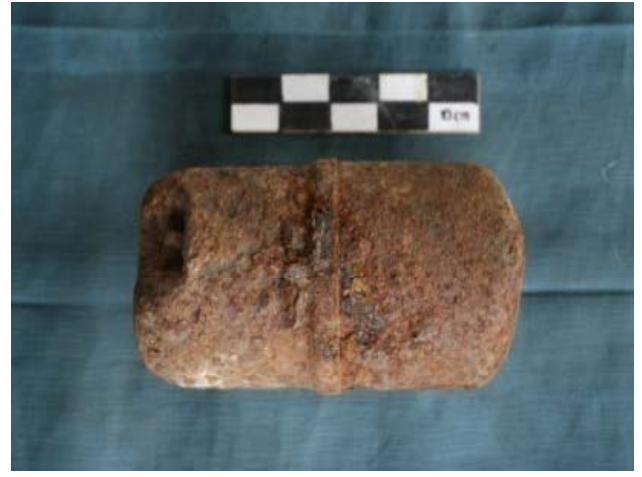

Foto 10. Koleksi berbahan logam besi

elektrolit lainnya, dimana udara atau elektrolit akan mengalami reduksi, sehingga proses korosi merupakan proses elektrokimia.

Korosi juga dapat terjadi oleh air yang mengandung garam, karena logam akan bereaksi secara elektrokimia dalam larutan garam (elektrolit).

Penghilangankorosipadabesidilakukandengan cara perendaman dengan menggunakan larutan jeruk nipis dengan $\mathrm{pH}$ 4-5. Waktu perendaman dilakukan berdasarkan tingkat ketebalan korosi.

Dalam jeruk nipis mengandung asam sitrat yang bersifat mampu mengkelat logam. Sehingga karat yang menempel pada logam besi mampu diikat dengan gugus karboksil dari asam sitrat.

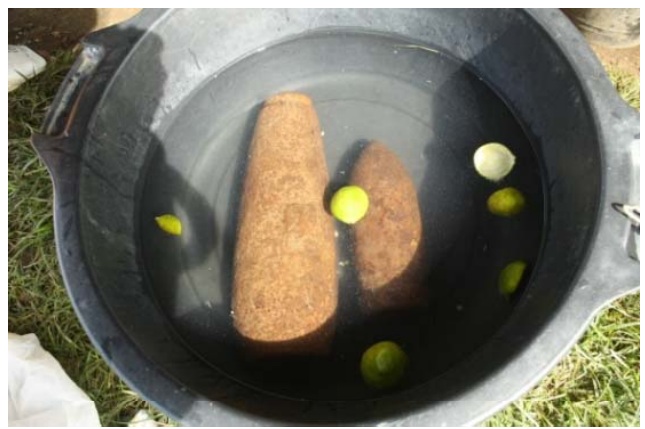

Foto 11. Perendaman koleksi dalam larutan air jeruk $\mathrm{pH}$ 4-5

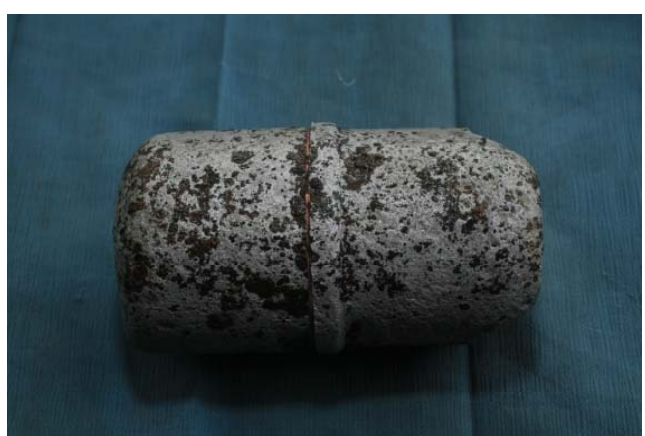

Foto 12 . Koleksi setelah dibersihkan dengan perendaman dalam larutan air jeruk

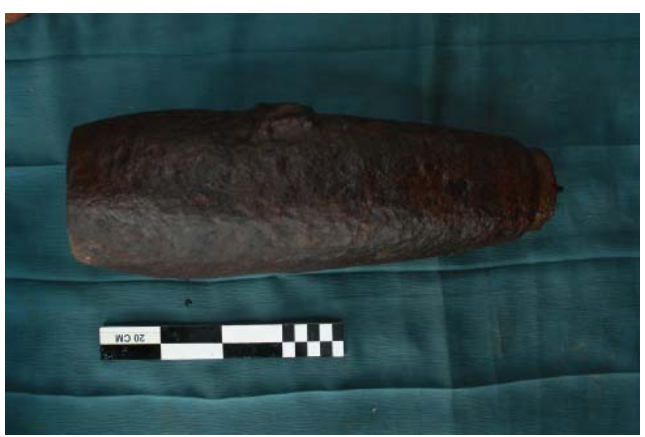

Foto 13. Koleksi proyektil peluru setelah dibersihkan dan dilapisi dengan minyak singer

3. Koleksi berbahan dasar aluminium.

Hasil observasi menunjukkan bahwa koleksi logam berbahan aluminium dalam kondisi yang lebih tahan daripada koleksi berbahan logam lainnya. Tingkat keterawatan objek ini masih cukup baik dibandingkan objek-objek yang lain.

Jenis koleksi yang berbahan logam aluminium memiliki tingkat kerusakan yang berbeda. Tidak semua jenis koleksi mengalami korosi ketika ditemukan. Untuk perlakuan cukup dilap dengan menggunakan air bersih.

Koleksi yang mengalami korosi berwarna hitam dilakukan pembersihan menggunakan pasta campuran antara soda kue dan jeruk nipis.

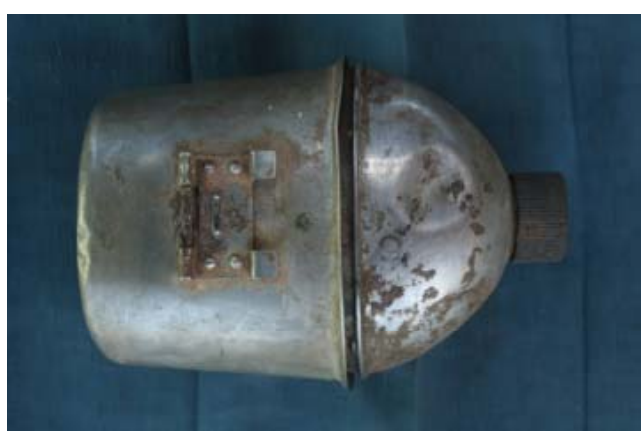

Foto 14. Koleksi tempat minum yang terbuat dari aluminium

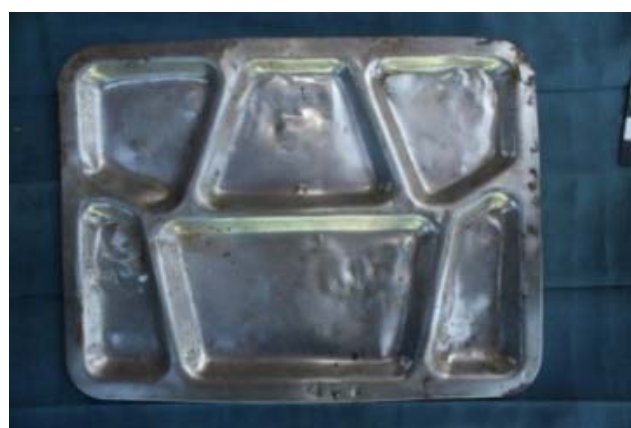

Foto 15 . Koleksi berbahan aluminium yang masih cukup bagus kondisinya 


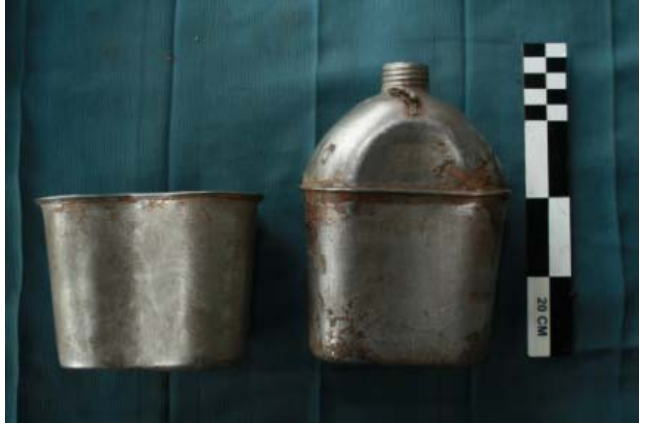

Foto 16 . Koleksi tempat minum yang terbuat dari aluminium setelah dibersihkan

\section{c. Koleksi Berbahan Porselen}

Disamping objek logam dan gelas terdapat beberapa objek yang terbuat dari porselen, baik yang berupa botol, lumping, gelas maupun cangkir.

Fungsi masing-masing objek ini pun bervariasi, ada yang digunakan sebagai alat minum, botol bedak dan sebagainya.

Hasil observasi menunjukkan bahwa pada koleksi berbahan porselen banyak terdapat endapan tanah. Secara fisik kondisi objek masih sangat bagus dengan indikasi tidak ditemukannya retakan baik kecil maupun besar.

Koleksi yang ditemukan terpendam tanah untuk jenis poselin tidak banyak mengalami kerusakan secara fisik. Pembersihan dari endapan tanah dengan cara mekanik menggunakan lap kemudian dibilas dengan menggunakan air bersih.

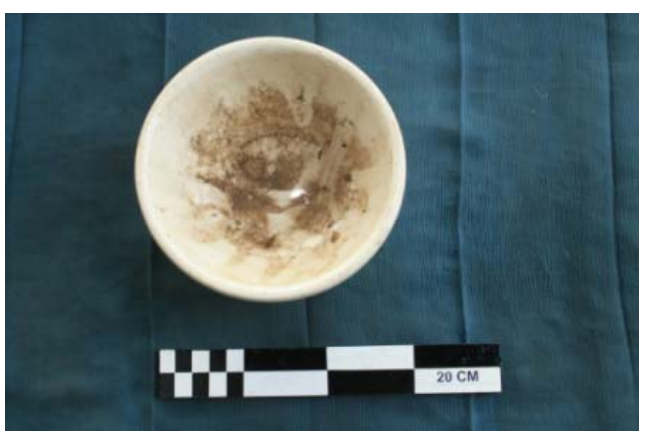

Foto 17. Endapan dari tanah pada Koleksi berbahan porselin

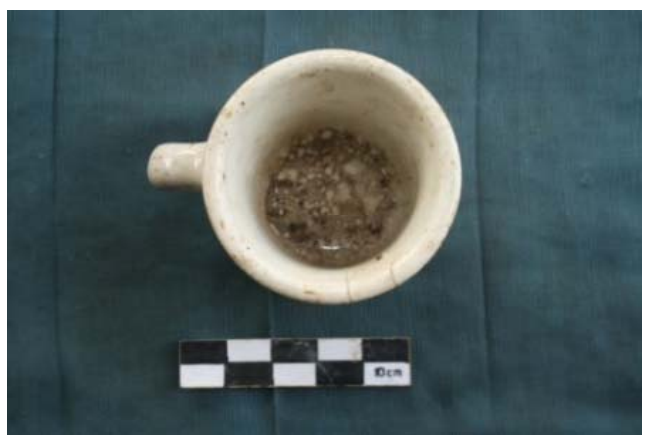

Foto 18 . Koleksi cangkir yang terbuat dari porselin

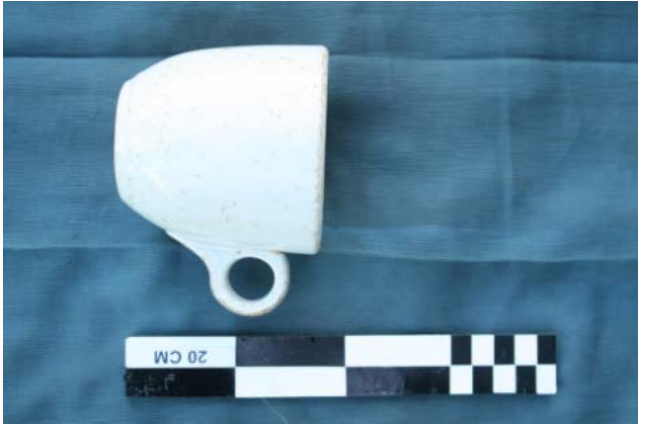

Foto 19. Koleksi cangkir setelah dibersihkan

Adapun untuk menghilangkan kerak yang menempel adalah dengan menggunakan pasta soda kue dan jeruk nipis.

d. Koleksi Lainnya (name tag tentara dan peralatan makan)

Koleksi lainnya yang akan dibersihkan adalah koleksi berupa name tag tentara berbahan logam baik logam aluminium maupun tembaga.

Koleksi name tag tentara yang ada di Museum Mini berjumlah 79 buah. Pada kegiatan ini belum semua koleksi yang berupa name tag dapat dibersihkan. Hanya beberapa koleksi yang dipilih untuk mewakili koleksi yang ada.

Selain koleksi mata uang logam/koin koleksi yang lain berupa peralatan makan seperti sendok dan garpu yang juga mengalami korosi.

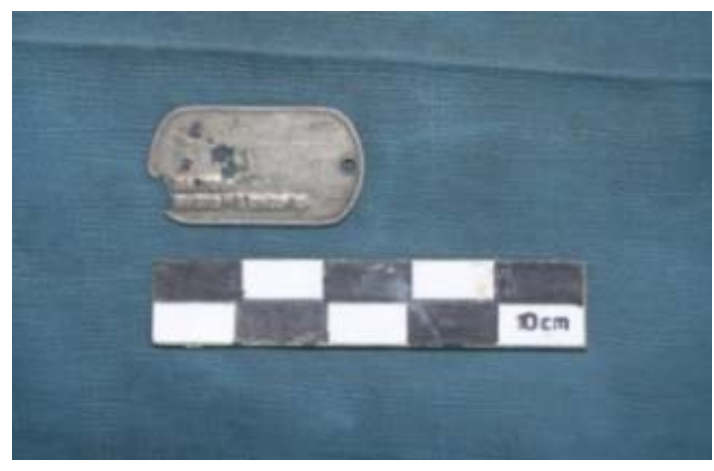

Foto 20. Name Tag berbahan aluminium

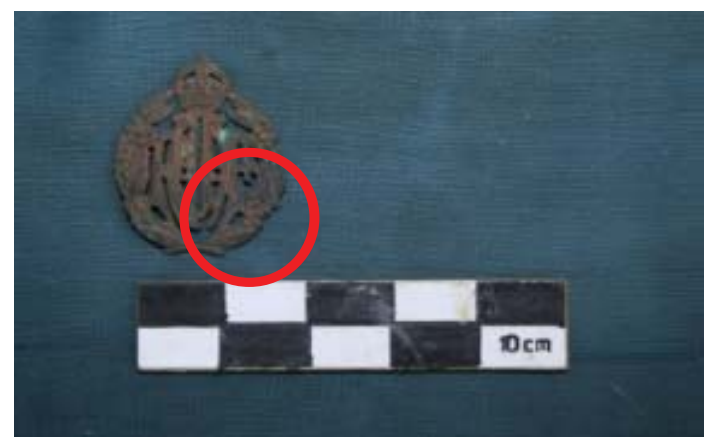

Foto 21. Name Tag berbahan tembaga yang telah mengalami korosi 


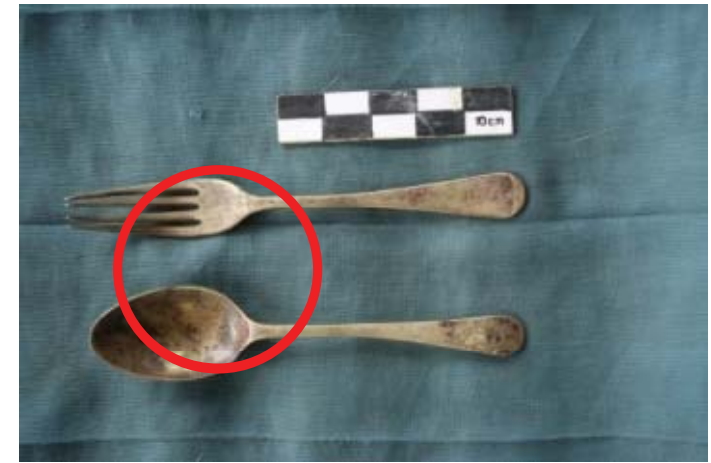

Foto 22. Koleksi sendok, garpu yang telah mengalami korosi

Proses penghilangan korosi dilakukan dengan cara penempelan pada bagian yang mengalami korosi menggunakan pasta yang terbuat dari soda kue dan jeruk nipis.

Berdasarkan hasil pembersihan menunjukkan hasil yang optimal dengan ditandai hilangnya warna hijau yang menempel pada koleksi berbahan dasar tembaga dan hilangnya warna hitam pada koleksi berbahan aluminium.

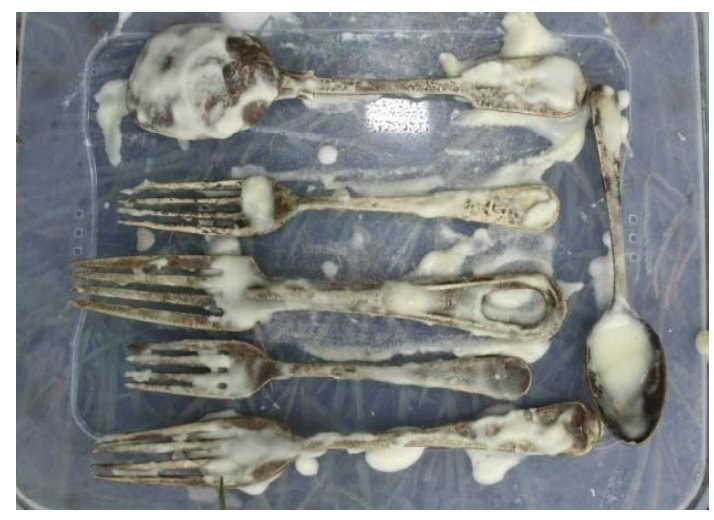

Foto 23. Penempelan korosi pada sendok, garpu dengan pasta soda kue dan jeruk nipis

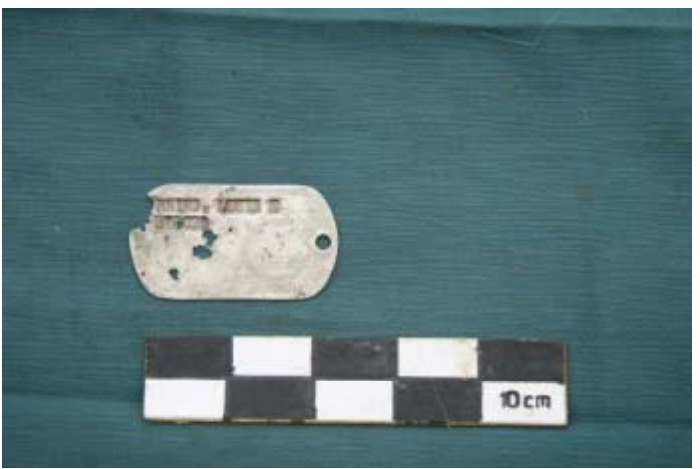

Foto 24. Name Tag setelah dibersihkan

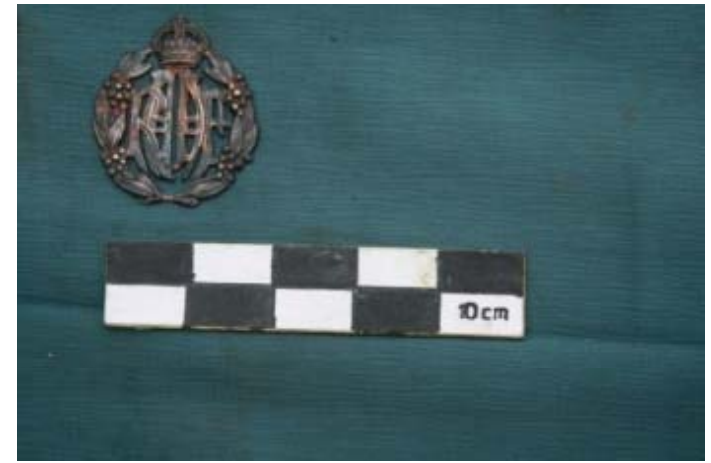

Foto 25. Name Tag setelah dibersihkan

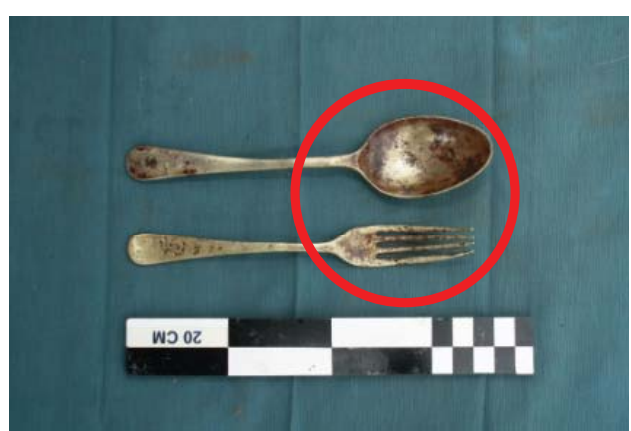

Foto 26. Koleksi Sendok dan Garpu setelah dibersihkan masih kurang optimal

Berdasarkan hasil pembersihan menggunakan pasta yang terbuat dari soda kue dan jeruk nipis terlihat bahwa koleksi sendok kurang optimal pembersihannya. Pada foto. 26 terlihat bahwa masih ada noda yang berwarna merah pada bagian cekungan. Hal ini dikarenakan korosi yang menempel pada sendok sudah terlalu tebal dan keras sehingga memerlukan aplikasi yang lebih lama atau harus dilakukan pengulangan penempelan pasta hingga korosi yang menempel dapat dihilangkan.

\section{B. Penyimpanan}

Hal penting yang harus dilakukan setelah proses pembersihan selesai adalah penyimpanan. Penyimpanan ini bertujuan untuk menjaga keterawatan koleksi yang telah dibersihkan agar benar-benar terjaga dari debu, kelembaban, dan cuaca.

Penyimpanan koleksi yang ada di Museum Mini ini dilakukan secara sederhana. Hal ini dikarenakan belum ada tempat penyimpanan yang memadai. Cara penyimpanan sementara yang dilakukan sebelum koleksi dipindahkan ke Museum Perang Dunia II adalah dengan cara membungkus koleksi menggunakan kertas tissue, kemudian dibungkus lagi dengan kertas koran, selanjutnya dimasukkan ke dalam container box. 


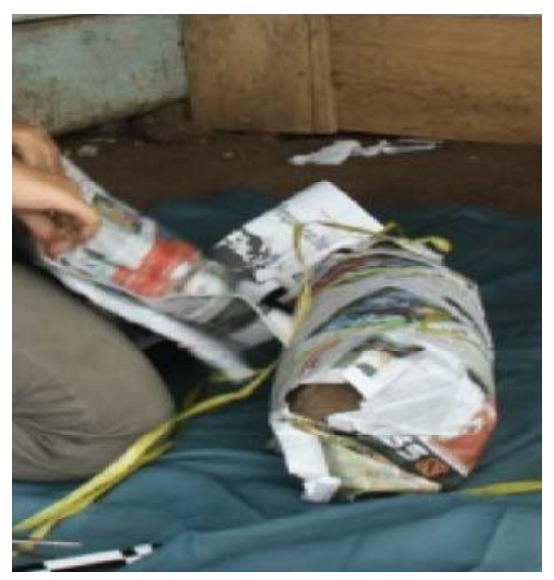

Foto 27. Pembungkusan koleksi dengan kertas Koran dan tissue

\section{BAB V. KESIMPULAN}

Metode pembersihan koleksi tinggalan kolonial cenderung menggunakan bahan yang mudah didapat yaitu dengn menggunakan pasta. Pasta tersebut merupakan campuran dari air jeruk dan soda kue yang kemungkinan belum pernah diteliti ataupun ditulis secara ilmiah.

Penggunaan metode seperti tersebut di atas menjadi alternatif utama dalam kegiatan konservasi kali ini. Hal ini dikarenakan untuk aplikasi dengan metode yang telah baku sulit untuk dilakukan karena keterbatasan bahan.

Pada kegiatan konservasi koleksi tinggalan kolonial dari berbagai macam bahan dapat disimpulkan bahwa :

1. Konservasi koleksi botol berbahan gelas dengan menggunakan bahan cuka, kerikil, sabun, dan air dinilai efektif untuk membersihkan kerak yang ada dalam botol gelas. Fungsi penggunaan bahan ini perlu diilmiahkan karena pengaplikasian metode ini didasarkan pada kebiasaan masyarakat.

2. Konservasi koleksi berbahan dasar logam terutama tembaga pada koleksi koin, proyektil peluru, selongsong peluru, dan name tag dengan menggunakan campuran air jeruk nipis

\section{Daftar Pustaka}

Sadirin, H.R.1979. Beberapa Metodologi Konservasi Benda-benda Purbakala. Magelang : Laboratorium Konservasi Borobudur.

1996. Pedoman Dasar-dasar Konservasi Benda-benda Purbakala. Magelang : Proyek Konservasi Candi Borobudur. dan soda kue (sodium bikarbonat) yang dibuat pasta, sangat efektif untuk membersihkan korosi (berwarna hijau kebiruan) pada permukaan logam. Metode pembersihan ini memiliki kelemahan yaitu, apabila pengaplikasiannya terlalu lama maka akan mengerus permukaan logam yang dibersihkan. Dengan demikian maka diperlukan monitoring lamanya aplikasi bahan pada obyek berdasarkan ketebalan korosi.

3. Konservasi koleksi logam berbahan besi pada koleksi proyektil dan senjata api dengan menggunakan asam sitrat konsentrasi 5\% dengan perendaman selama 1 malam. Berdasarkan hasil aplikasi, bahan ini dinilai sangat efektif untuk membersihkan korosi (berwarna merah kecoklatan) yang ada pada permukaan logam.

4. Konservasi koleksi porselen dapat dilakukan dengan 2 cara yaitu untuk endapan tanah yang menempel pada permukaan porselen dengan cara dibersihkan dengan menggunakan air dan sabun. Sedangkan untuk menghilangkan kerak yang tebal dan sulit dihilangkan dapat menggunakan campuran antara jeruk nipis dan soda kue yang berbentuk pasta. Pengunaan bahan ini secara visual sangat efektif untuk membersihkan noda pada koleksi porselen akan tetapi masih diperlukan penelitian yang lebih lanjut.

5. Tahapan terakhir yang dinilai penting setelah melakukan konservasi adalah penyimpanan koleksi. Setiap koleksi disimpan dengan cara dibungkus menggunakan tissue dan kertas Koran. Tempat penyimpanan sementara yang digunakan dapat berupa box kontainer yang diberi kapur tulis. Kapur tulis yang ditambahkan dimaksudkan untuk menyerap kelembaban udara di dalam kontainer. Aplikasi metode ini belum diketahui seberapa jauh keefektifannya untuk menghambat korosi sehingga diperlukan monitoring secara berkala.
1997. "Teknologi Konservasi Benda Cagar Budaya". Seminar Pemugaran dan Konservasi Benda Cagar Budaya Tingkat Direktorat. Jakarta : Direktorat Jenderal Kebudayaan.

Suhardi, Nahar Cahyandaru, Sudibyo, 2008, Konservasi Keramik, Balai Konservasi Peninggalan Borobudur, Magelang. 
Sudiono. 1993. "Metode Konservasi Benda

Perunggu". Analisis Hasil Penelitian

Arkeologi IV halaman 301-310.

Jakarta : Departemen Pendidikan dan

Kebudayaan.

Yulita, Ita. 2008. Konservasi Preventif di Museum., Museografia Vol II No 2 Oktober 2008., Direktorat Museum, Departemen Kebudayaan dan Pariwisata.

\section{Website}

http://www.greenshop.co.uk/Sodium Bicarb Uses.pdf

http://www.ehow.com/how 5083626 clean-metal naturally.html\#ixzz2gd1ASZwa

http://oconto.uwex.edu/files/2011/02/Baking-Soda. pdf

http://www.scribd.com/doc/93731415/Bab-6Material-Tahan-Korosi 